\title{
The Ebstorf Map: tradition and contents of a medieval picture of the world
}

\author{
G. Pischke \\ Institut für Historische Landesforschung der Universität Göttingen, Göttingen, Germany \\ Correspondence to: G. Pischke (dr.pischke@gmx.de)
}

Received: 6 May 2014 - Accepted: 29 May 2014 - Published: 11 July 2014

\begin{abstract}
The Ebstorf Map (Wilke, 2001; Kugler, 2007; Wolf, 2004, 2006, 2007, 2009a, b), the largest medieval map of the world whose original has been lost, is not only a geographical map. In the Middle Ages, a map contained mystic, historical and religious motifs. Of central importance is Jesus Christ, who, in the Ebstorf Map, is part of the earth. The Ebstorf Map contains the knowledge of the time of its creation; it can be used for example as an atlas, as a chronicle of the world, or as an illustrated Bible.
\end{abstract}

\section{Origin}

The original of this mappa mundi from the 13th century $\mathrm{AD}$ (Wolf, 2006), measuring 3.58 by $3.56 \mathrm{~m}\left(=12.74 \mathrm{~m}^{2}\right)$, was discovered around 1830 at the convent of Ebstorf (Germany, Lower Saxony, in the Lüneburger Heide region) and named after it. The map was created in this monastery, which was first founded as a convent of canons around 1160 and soon after, around 1190, refounded as a convent for Benedictine nuns (Dose, 2012). Opinions differ not only concerning the exact time or time period of its creation, but also concerning its authorship, patronage and ultimate purpose.

\section{Rediscovery, first publication, loss, and reproduction}

After the rediscovery of the map an unknown hand cut out pieces from the top right-hand corner; parts missing on the left are due to damage done by mice during storage. Thus the map is incomplete (Fig. 1). The original consisted of 30 single pieces of sheepskin parchment that had been sewn together and rolled up. In 1834 it was taken to the Vaterländisches Archiv in Hanover and later added to the map collection of the Historischer Verein für Niedersachsen there, which was founded in 1835. In 1838 the first measures to preserve the map were taken, in 1888 at the Königliches Kupferstichkabinett in Berlin it was taken apart, cleaned, smoothed and stretched. Then it was kept in single pieces put into frames in a chest of drawers at the Hauptstaatsarchiv in Hanover.
After a first description by Blumenbach (1834), Sommerbrodt (1891) and Miller (1896) created facsimile editions, the former consisting of 25 phototypes, the latter as a lithography, and in 1898 a coloured version followed. The facsimiles and a coloured version of one of the Sommerbrodt reproductions, produced in 1930 based on the original, form the basis of recent reproductions of the Ebstorf world map, as the original was burnt during the air raid on Hanover of the night from 8 to 9 October 1943. From this material, painter and graphic artist Rudolf Wieneke created four reproductions on goatskin parchment in 1951/1953, commissioned by the board of the Museumsverein für das Fürstentum Lüneburg: one is kept at the convent of Ebstorf, one in Lüneburg and one on the Plassenburg near Kulmbach (Germany, Bavaria); the fate of the fourth reproduction, which was given as a present to the Queen of Greece in 1956, is unknown.

\section{Mappa mundi in general}

Even centuries before the Ebstorf Map was made, maps of the world existed, mappae mundi, of varying compactness of information. There were e.g. the four-continent map (one continent was yet to be discovered) by Krates of Mallos (2nd century BC) (Seyffert et al., 1956) zonal maps like the five-zone map by Macrobius (late 4th century AD) (Stahl, 1952), the wheel-shaped tripartite maps by Isidore of Seville (ca. 560-636) (Möller, 2008) Al-Istakhri (around 934) (Harley and Woodward, 1994), Lambert of St Omer 


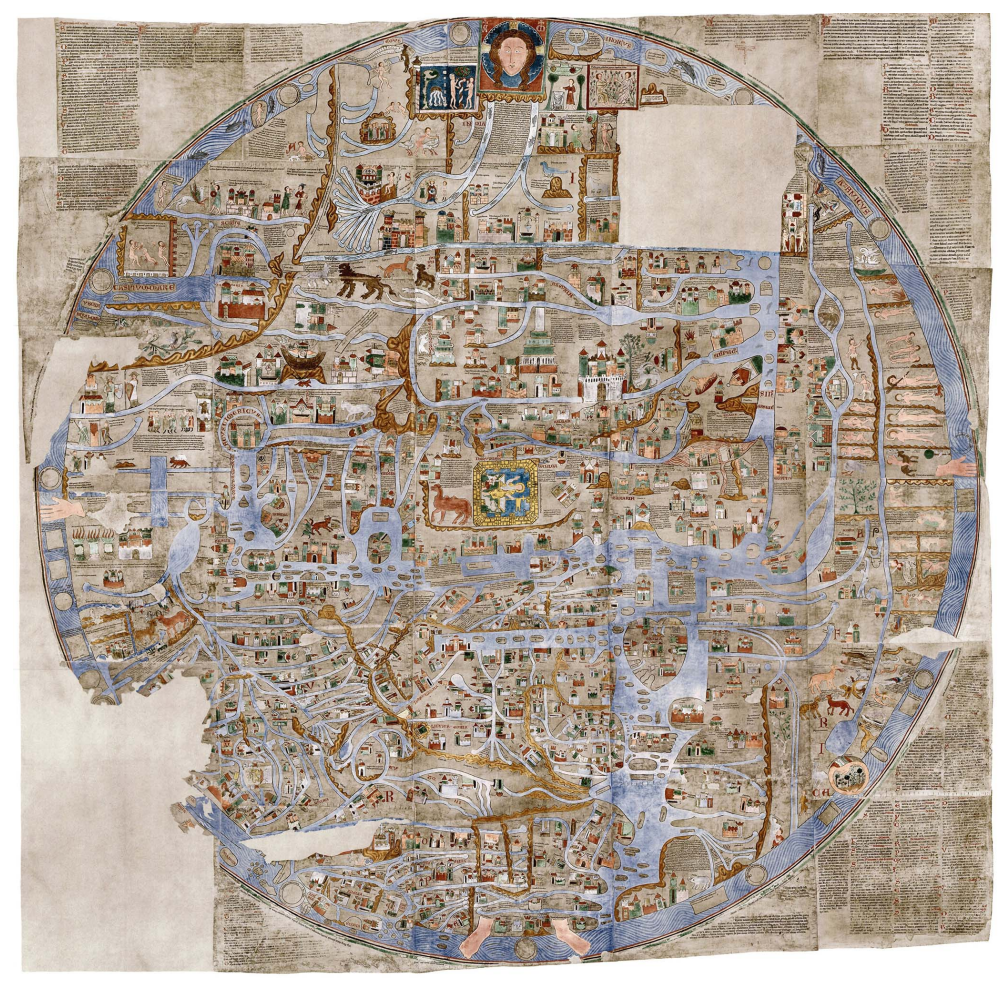

Figure 1. The whole Ebstorf mappa mundi (Kugler, 2007). The whole map symbolises Christ with his head on top (east), his hands to the right (south) and left (north), and his feet at the bottom (west). In the middle Jerusalem is depicted with the rising Christ on a blue background. Below is the T-shaped Mediterranean, separating Asia (to the east, top), Europe (to the northwest, lower left), and Africa (to the south, lower right). A high-resolution version (4047x3964 pixel) is available at http://www.landschaftsmuseum.de/Seiten/Museen/Ebstorf1.htm (Abb. 2).

(1112-1121) and Henry (Heinrich) of Mayence (1109/1110) or the Hereford mappa mundi (before 1278, lost; copy from around 1300, cf. Wolf 2009a). Several of these maps are illustrations belonging to manuscripts or miniatures: in Isidore's Etymologiae (printed in 1472), or in Lambert of St Omer's Liber Floridus (Luckhardt and Niehoff, 1995), or the world map Henry of Mayence put before the Imago mundi by Honorius Augustodunenesis (1109-1110, lost; copy 11801190) (Luckhardt and Niehoff, 1995), or the psalter world map created around 1250 (London, British Library). The Hereford mappa mundi (Harvey, 2006), in contrast, measures 1.35 by $1.65 \mathrm{~m}$. Tripartite maps follow the "T and O pattern": a "T" parts a circle (="O"), the earth, into three parts: Asia is on top, underneath there are Europe on the left and Africa on the right. The Ebstorf Map varies this pattern slightly by not showing Africa in the bottom right quarter, but along the right margin of the map.

\section{Special features of the Ebstorf mappa mundi}

The Ebstorf mappa mundi clearly differs from its predecessors, not only in size and in the compactness of information shown by the large number of entries - 2345, of which 1500 are texts and 845 pictures (500 buildings, 160 rivers, lakes, seas and other waterways, 60 islands or mountains, 45 people or mythical persons, and 60 animals) - but also in the twofold representation of Christ and numerous religious motifs. This map is orientated towards the east like all medieval mappae mundi - with the exception of the Islamic maps orientated towards the south. In it, the earth forms Christ's body: on top, in the east, there is his head, on the left in the north and on the right in the south there is one hand each, one hand showing a stigma, and at the bottom in the west there are his feet. Sicily, heart-shaped and placed on the right slightly below the centre, can be interpreted as Christ's heart. This means that Jesus Christ keeps the world together, and is part of this world, like humankind whom he rules in eternity, and the world is part of Christ as his body. In a gold-framed area in the centre of the map the Resurrection is shown within the walls of the heavenly Jerusalem, a city towering above all the world - thus the text of the caption - as the first of all cities (Fig. 2). Biblical motifs included in the Ebstorf mappa mundi are e.g. Paradise with Adam and Eve, showing the Fall of Man tempted by the serpent - which is shown here as male and bearded - (Fig. 3a) ${ }^{1}$, Noah's Ark on Mount Ararat (Fig. 3a), or the Israelites' way through the Red Sea (Fig. 3b), as well as

\footnotetext{
${ }^{1} \mathrm{~A}$ convenient tool for finding certain details on the map is a hypermap provided by Leuphania University, Lüneburg, Germany, unfortunately only in German: http://www2.leuphana.de/ebskart/.
} 


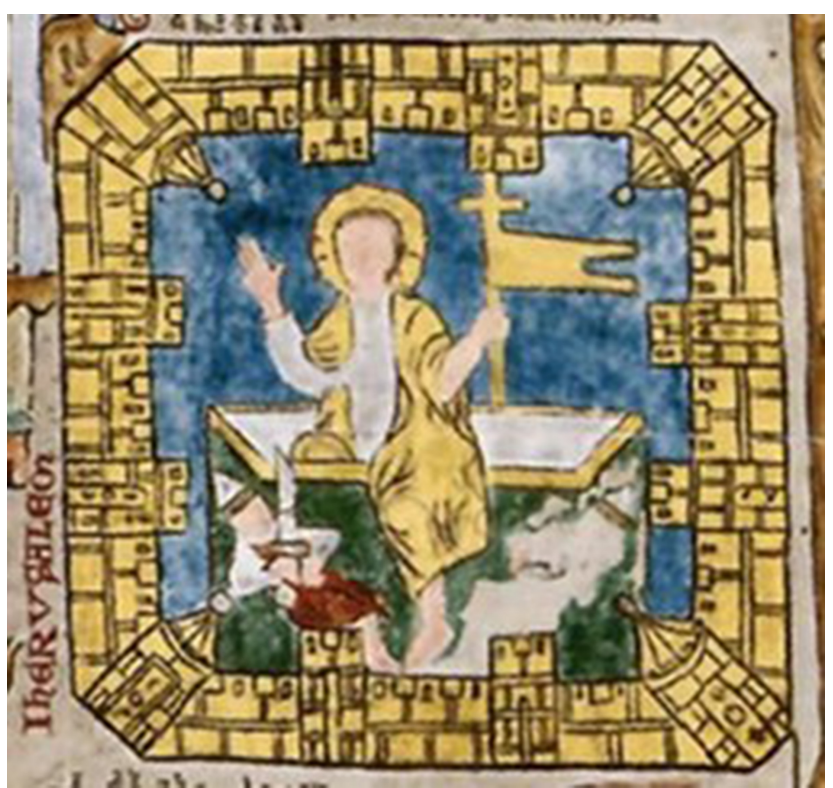

Figure 2. Centre of the map, the "heavenly Jerusalem" (rotated anticlockwise by $90^{\circ}$ ).

places from the Old Testament like Hebron (Fig. 3d), Mount Sinai (Fig. 3b), Babylon with the Tower of Babel (Fig. 3b), or Sodom and Gomorrah, sunk in the Dead Sea (Fig. 3b), and from the New Testament places like Bethlehem (Fig. 3d), Nazareth (Fig. 3b), Cana (Fig. 3b), Capernaum (Fig. 3b) or Gethsemane, also places related to the life and travels of the apostle Paul, and finally graves of apostles (e.g. Fig. 3a).

\section{Contents of the Ebstorf Map}

Elaborated from the writings known and accessible in the 13th century, the Ebstorf Map contains the knowledge of the time, from theology to geography, secular history, the history of salvation, well-founded as well as legendary and mythical knowledge. This spans from Adam and Eve to Alexander the Great, to the origins of the Saxons and the Crusades; only the religious world of Islam is excluded. The most recent source integrated is Gervasius of Tilbury's Otia imperialia (Stiene, 2009), written in 1214 and dedicated to Emperor Otto IV, Gervasius being identified by some as the author of the Ebstorf Map (Wolf, 2004, 2009a). The Ebstorf Map can be viewed under different aspects: geographically as a map, didactically as an encycoplaedic teaching means, iconographically as a depiction of God's creation of the world, in the context of the history of piety as a devotional image, politically as a symbol of power, and synoptically as a chronicle of the world projected onto parchment; in a shorter way as an atlas, as a world chronicle, as an illustrated Bible, but also as a collection of myths and legends, thus a book of anecdotes and for entertainment, and even as a zoological handbook, because it mentions and shows animals - mam- mals (e.g. elephant, giraffe, bear, lion, antelope, horse, elk), reptiles (e.g. snake, chameleon, crocodile), birds (e.g. parrot, pelican, crane, ibis), insects (e.g. ants) and fabulous creatures (e.g. dragons). In contrast to all this animal life, flora is only depicted sparingly and is only used for purposes of decoration. All this is spread over the continents: Asia (on top, in the east), Europe (on the left, in the north) and Africa (on the right, in the south). Asia covers the largest part of the map, followed by Europe; special features of the continents and countries shown have been put into texts and pictures. The Black Sea and the Mediterranean (in a T shape) divide Europe from Asia (Fig. 3c, d); the Mediterranean also divides Europe from Africa (Fig. 3d), and the Red Sea forms the border between Asia and Africa (Fig. 3b, d). Next to the twelve winds in the margin of the map the ocean is outlined; this is a hint of the medieval knowledge of the spherical shape of the earth which was to be represented as a circle if showing the surface of the earth. Although it is orientated along the usual travel routes, the Ebstorf Map is not geographically accurate; also, it is not possible to identify all its entries beyond any doubt.

In Asia (Fig. 3a, b), depictions of cities (e.g. Antiochia (Fig. 3a), Ephesos (Fig. 3a), Lo Yang (Fig. 3a), Samarkand, (Fig. 3a)) alternate with Biblical motifs (Jesus' travels, the grave of St Bartholomew, Fig. 3a), real people (the Chinese, Fig. 3a) and mythical peoples (e.g. cannibals, Fig. 3a, Amazons, Fig. 3a); furthermore, there are the stages of Alexander's expedition against the Persian Empire (334-324 BC) such as Persepolis (Fig. 3b), which was destroyed by him in 330 BC. Africa (Fig. 3b, d) appears as a largely unknown continent: whereas Cairo (Fig. 3b), Alexandria (founded by Alexander the Great in 332/331 BC, Fig. 3d) and Marrakesh (Fig. 3d) and ancient cities like Carthage (Fig. 3d, destroyed by Rome in 146 BC), the Atlas Mountains (Fig. 3d) and the sources of the Nile (Fig. 3b) are shown, it is pictures of animals and fabulous peoples that are dominant, such as the "cave dwellers" (trogodytes, Fig. 3d) or "snake eaters" (ophiophagi, Fig. 3d). Apart from the Bible, Asia and Africa also reflect Greek and Roman ancient history; medieval Asia is integrated by including Baghdad (Fig. 3b), the political centre of the Islamic world, Damascus (Fig. 3a) as a trade centre and further cities situated on trade routes such as the Silk Road.

Europe (Fig. 3a, c, d) - shown from the Urals (Fig. 3a) to the Strait of Gibraltar (Fig. 3d), from the Northern Ocean (Fig. 3a, c) to Sicily (Fig. 3d), including cities (e.g. Novgorod, Riga, Kiev, Antwerp, Paris, Saragossa/Zaragoza (Caesar Augusta), Rome, Athens, Venice), mountains and mountain ranges (e.g. the Pyrenees, Mount Etna), rivers (e.g. Don, Vistula, Danube, Loire, Po) and islands of the Mediterranean - is dominated by the Holy Roman Empire (Fig. 3c). Shown from Frisia to Zurich, from Prague to Aachen, within the empire cities and rivers like the Rhine and the Main are depicted, and the island of Reichenau in Lake Constance with its three monasteries, which is especially accentuated; within 


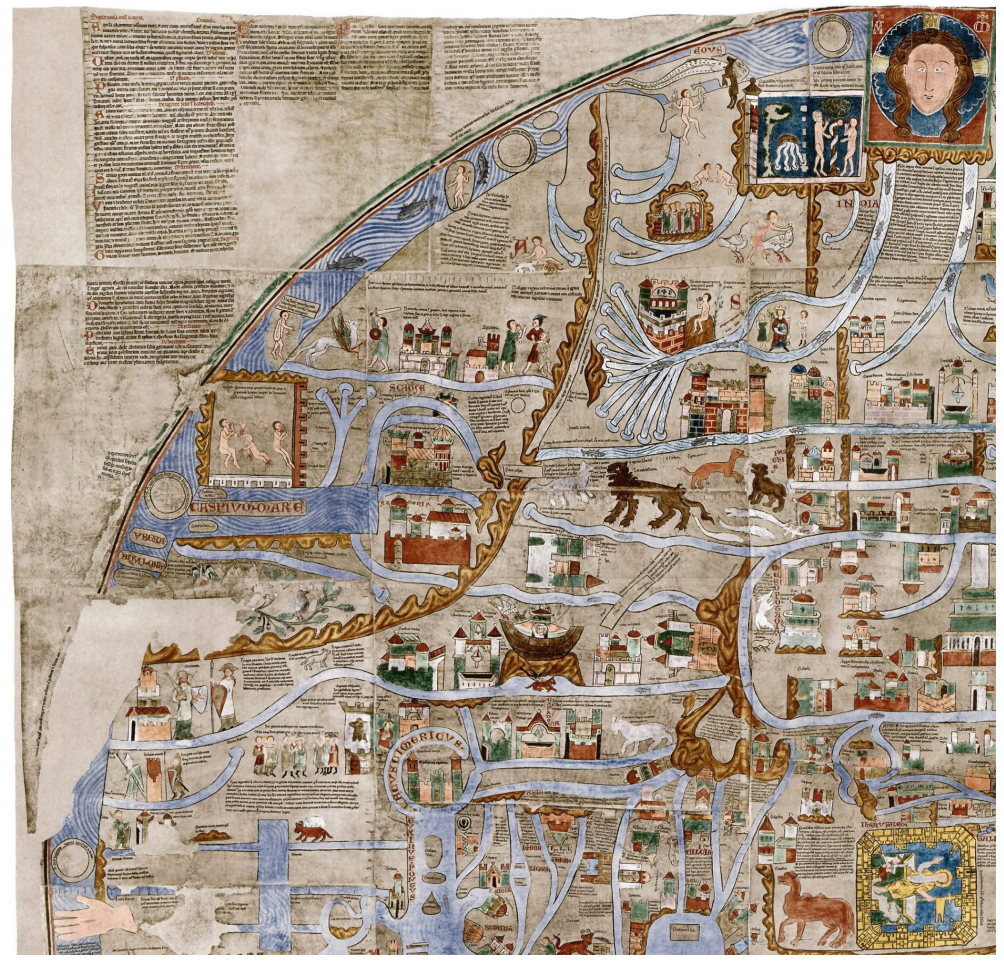

Figure 3a. Upper left quadrant of the map. East is towards the top, north to the left. In the middle of the map (in this quadrant in the lower right corner) the heavenly Jerusalem is depicted (Fig. 2). This part of the map shows Asia.

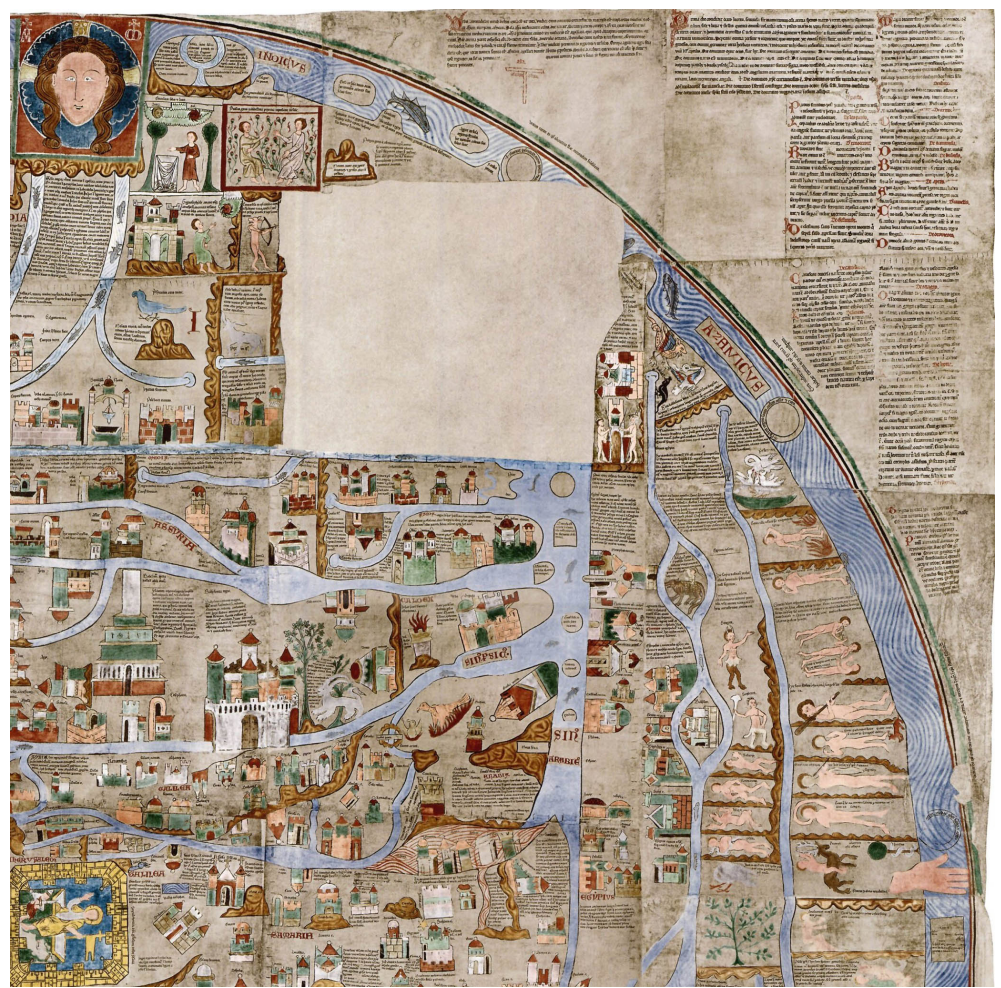

Figure 3b. Upper right quadrant of the map (partly overlapping with Fig. 3a). At the bottom left is the heavenly Jerusalem; at the bottom right Christ's left hand can be seen which points toward south. This part of the map also depicts Asia. 


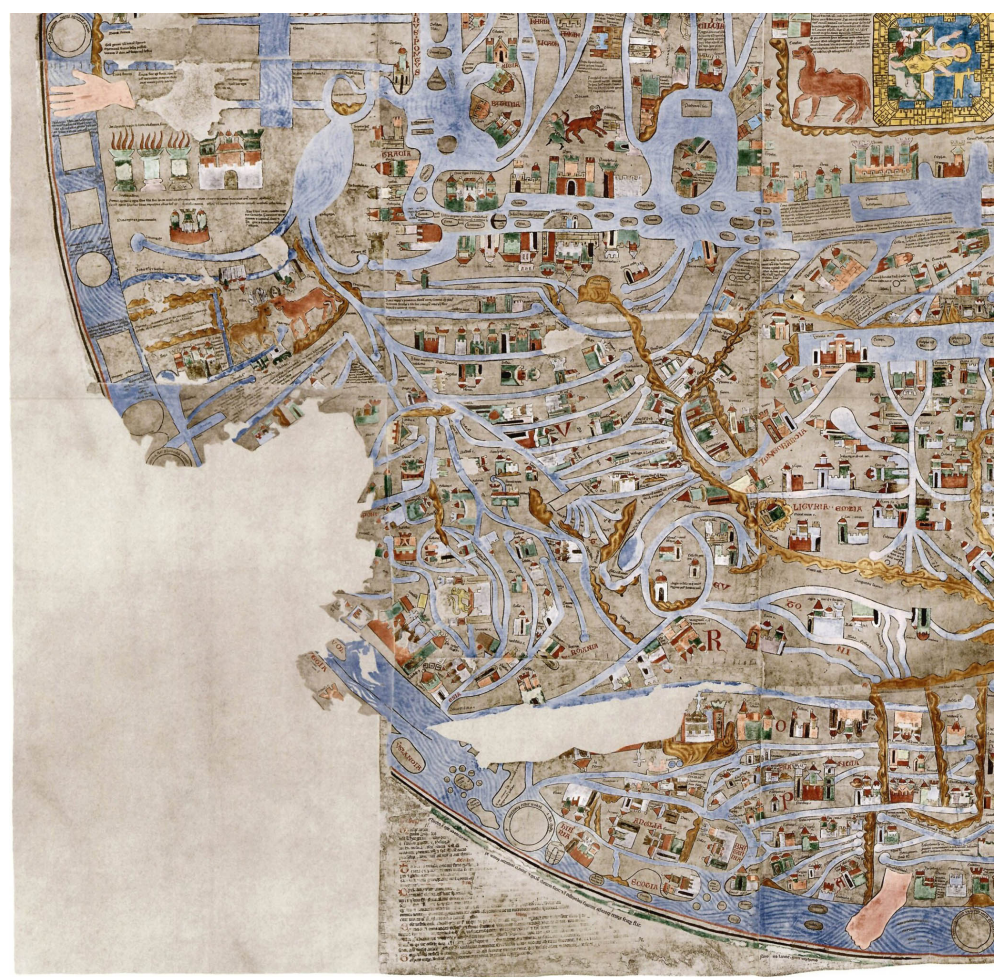

Figure 3c. Lower left quadrant of the map (partly overlapping with Fig. 3a and b). Christ's right hand can be seen in the upper left corner and his right foot in the lower right corner (pointing towards west). This quadrant depicts Europe. Part of the map was nibbled off by mice.

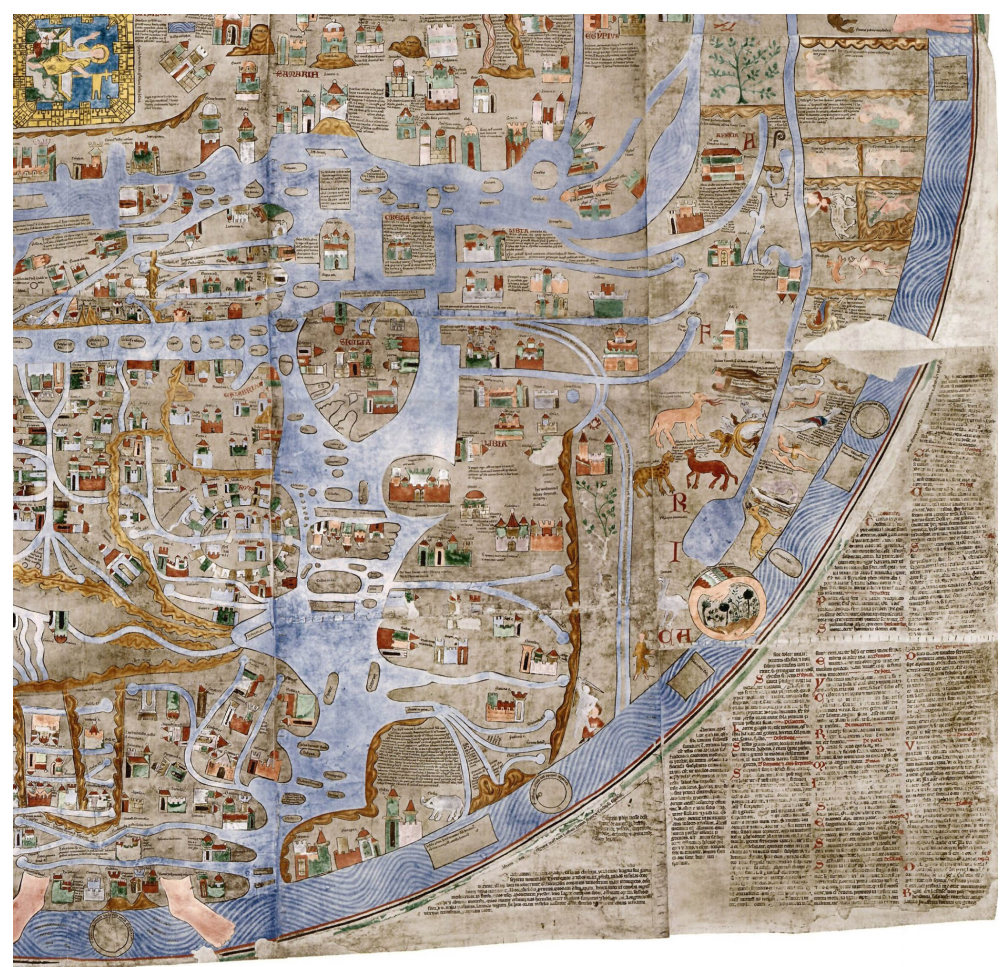

Figure 3d. Lower right quadrant of the map (partly overlapping with the other three figures). The T-shaped Mediterranean with many islands is painted in blue. In the middle, the heart-shaped island of Sicily symbolises Jesus' Sacred Heart. To the right of it Africa is depicted. 


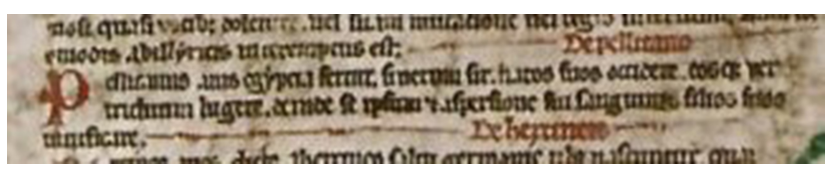

Figure 4. Example of a text insert about the pelican. The English translation of the Latin text reads: the pelican is an Egyptian bird which does, if it is true, kill his young ones and mourn them for three days, and then revives them with his own blood.

the empire, Saxony is shown especially large and detailed (Fig. 3c): in addition to the central cities of the Guelphs, Brunswick with its lion and Lüneburg with its banner, the convent of Ebstorf with the graves of the martyrs is depicted, and so are cities - not only bishops' sees - such as Bremen, Verden, Essen, Paderborn, Hanover, Hildesheim, Gandersheim, Goslar, Quedlinburg, Halberstadt, Magdeburg, Erfurt, Naumburg; apart from the Weser river the rivers Elbe, Saale, Leine, Aller, Oker, Ilmenau, Ohre, Bode, Fulda and Gera are also shown.

Outside the actual map in the four corners or spandrels there are additional marginal texts containing information e.g. on the concept behind the map, the creation of the world represented as a map, the cosmos as the framework behind the map, the macrostructure of the world, but also about animal life (e.g. land-dwelling animals, reptiles, birds) (Fig. 4), about minerals, islands and much more. The writing on the map - majuscules and minuscules in black and red - can be classified as Gothic book hand: in the geographic labels bigspaced majuscules in red are used for continents, small majuscules in red for countries and regions (some also spaced), further regions being in black, whereas black minuscules are used for cities, mountain ranges and rivers (all the text inserts can be found on the web page given in footnote 1).

\section{Unanswered questions}

Despite all attempts of the last few decades to find out about the initiator, the author and the patron of this mappa mundi and also about its purpose (means of education? - decoration? - devotion?), no decisive conclusions can be reached. It also remains obscure when and why the map was hidden or forgotten at the convent of Ebstorf - perhaps this happened in the context of the Protestant Reformation and in connection with the transformation of the monastery into a Protestant religious institution for ladies.

Acknowledgements. The author thanks U. Richter-Uhlig, Göttingen for translations into English.

The text is also based on the results of the work of the students named below who took part in a project seminar at the Seminar für Mittlere und Neuere Geschichte at Göttingen University in the summer term of 2010: G. Bark, C. Cornelius Brinckmann, M. Bührig, N. Depzinski, L. Fernández, F. Fuhg, S. Gerle,
S. Grußendorf, M. Kahla, M. Klika, A. Kusnezow, D. Meiser, M. A. Müller, V. Naumann, M. Nitsch, J. Rüdiger, S. Schütze, R. Schwegmann, N. Urbigkeit, and F. Valgolio.

Edited by: G. P. Gregori

Reviewed by: P. Aufgebauer and G. Köbler

\section{References}

Blumenbach, G. H. W.: Beschreibung der ältesten bisher bekannten Landkarte aus dem Mittelalter im Besitz des Klosters Ebstorf, in: Vaterländisches Archiv, Hahnsche Buchhandlung, 1-21, 1834

Dose, H.: Ebstorf - Prämonstratenser, ab ca. 1190 Benediktinerinnen, ab 1565 Damenstift (ca. 1160 bis zur Gegenwart), in: Niedersächsisches Klosterbuch, Verzeichnis der Klöster, Stifte, Kommenden und Beginenhäuser in Niedersachsen und Bremen von den Anfängen bis 1810, Veröffentlichungen des Instituts für Historische Landesforschung der Universität Göttingen, 56, 1, 351-360, Bielefeld, 2012.

Harley, J. B. and Woodward, D. (Eds): The history of cartography, Vol. 2, Book 1, Univ. of Chicago Press, Chicago, (see also: http:// en.wikipedia.org/wiki/Estakhri (last access: 30 June 2014), 1994.

Harvey, P. D. A. (Ed.): The Hereford world map: medieval world maps and their context, British Library, London, 2006.

Kugler, H.: Die Ebstorfer Weltkarte, Kommentierte Neuausgabe in 2 Bänden, Akademie Verlag, Berlin, 2007.

Luckhardt, J. und Niehoff, F. (Eds.): Heinrich der Löwe und seine Zeit. Herrschaft und Repräsentation der Welfen 1125-1235, Katalog der Ausstellung Braunschweig, Hirmer Verlag, Bd. 1, 2005.

Miller, K.: Kurze Erklärung der Weltkarte des Frauenklosters Ebstorf, Bachem, Köln, 1896.

Möller, L.: Die Enzyklodädie des Isidor von Sevilla, Marix Verlag, Wiesbaden, 2008.

Seyffert, O., Nettleship, H., and Sandys, J. E. (Eds.): Crates of Mallos in Cilicia, in: A dictionary of classical antiquities: mythology, religion, literature, art, Meridian, New York, (see also: http: //de.wikipedia.org/wiki/Krates_von_Mallos (last access: 30 June 2014), 1956.

Sommerbrodt, E. (Hrsg.): Die Ebstorfer Weltkarte, im Auftrage des Historischen Vereins für Niedersachsen, Text und Tafeln, Hannover, 1891.

Stahl, W. H.: Commentary on the dream of Scipio, Columbia, University Press, New York, (see also: http://en.wikipedia.org/wiki/ Macrobius (last access: 30 June 2014), 1952 (translated from Latin).

Stiene, H. E.: Kaiserliche Mußestunden = Otia imperialia / Gervasius von Tilbury, Halbband 1 und 2, Bibliothek der mittellateinischen Literatur, 6, Stuttgart, 2009.

Wilke, J.: Die Ebstorfer Weltkarte, 1. Textband, 2. Tafelband, Veröffentlichungen des Instituts für Historische Landesforschung der Universität Göttingen, Nr. 39, Verlag für Regionalgeschichte, Bielefeld, 2001. (contains all the older publications).

Wolf, A.: Albert oder Gervasius? Spät oder früh? Kritische Bemerkungen zu dem Buch von Jürgen Wilke über die Ebstorfer Weltkarte, in: Niedersächsisches Jahrbuch 76, 285-318, Hahnsche Buchhandlung, 2004.

Wolf, A.: Kriterien zur Datierung des Ebstorfer Weltkarte, in: Kloster und Bildung im Mittelalter, herausgegeben von: Kruppa, N. und Wilke, J., Vandenhoeck \& Ruprecht, 425-469, 2006. 
Wolf, A.: Rezension “ Hartmut Kugler, Die Ebstorfer Weltkarte, kommentierte Neuausgabe in 2 Bänder, Berlin, 2007”, in: Niedersächsisches Jahrbuch, 79, 426-431, 2007.

Wolf, A.: Die "Ebstorfer Karte" und Gervasius von Tilbury - ein Weltbild im Umkreis des Kaisers, in: Otto IV - Traum vom welfischen Kaisertum, herausgegeben von: Braunschweigisches Landesmuseum, 195-206, 2009a.
Wolf, A.: Gervasius von Tilbury, Arelatischer Marschall Ottos IV. und die Ebstorfer Weltkarte, in: Salzgitter Jahrbuch, Geschichtsverein Salzgitter e.V., 157-188, 2009b. 